\title{
Medical Geology: Impacts of the Natural Environment on Public Health
}

\author{
Jose A. Centeno ${ }^{1, *}$, Robert B. Finkelman ${ }^{2, \dagger}$ and Olle Selinus ${ }^{3,+}$ \\ 1 Center for Devices and Radiological Health, Office of Science and Engineering Laboratories, \\ Division of Biology, Chemistry and Materials Science, US Food and Drug Administration, \\ White Oak Campus, Silver Spring, MD 20993, USA \\ 2 Geosciences Department, University of Texas at Dallas, 800 W. Campbell Road, Richardson, TX 75080-3021, \\ USA; bobf@utdallas.edu \\ 3 Linneaus University, Linnegatan 2, Kalmar 39233, Sweden; olle.selinus@gmail.com \\ * Correspondence: jose.centeno@fda.hhs.gov; Tel: +1-301-796-2487 \\ + These authors contributed equally to this work.
}

Academic Editor: Jesus Martinez-Frias

Received: 19 January 2016; Accepted: 27 January 2016; Published: 1 February 2016

All living organisms are composed of major, minor, and trace elements, given by nature and supplied by geology. Medical geology is a rapidly growing discipline dealing with the influence of natural geological and environmental risk factors on the distribution of health problems in humans and animals [1-3]. As a multi-disciplinary scientific field, medical geology has the potential of helping medical and public health communities all over the world in the pursuit of solutions to a wide range of environmental and naturally induced health issues.

The natural environment can impact health in a variety of ways. The composition of rocks and minerals are imprinted on the air that we breathe, the water that we drink, and the food that we eat. For many people this transference of minerals and the trace elements they contain is beneficial as it is the primary source of nutrients (such as calcium, iron, magnesium, potassium, and about a dozen other elements) that are essential for a healthy life. However, sometimes the local geology may contain minerals than contain certain elements that naturally dissolve under oxidizing/reducing conditions in groundwater. In excess, these elements can cause significant health problems because there is an insufficient amount of an essential element, or an excess of such elements (such as arsenic, mercury, lead, fluorine, etc.), or gaseous combinations, such as methane gas, an over abundance of dust-sized airborne particles of asbestos, quartz or pyrite, or certain naturally occurring organic compounds. The latter includes findings reported by the U.S. Geological Survey that even groundwater passing through some lignite beds can dissolve PAHs in sufficient concentrations to cause serious health issues [4].

Current and future medical geology concerns include: elevated levels of arsenic in drinking water in dozens of countries including the USA; mercury emissions from coal combustion and its bioaccumulation in the environment; the impacts of mercury, arsenic, and lead mobilizations in surface and ground water in regions were artisanal gold mining is conducted; the residual health impacts of geologic processes such as volcanic emissions, earthquakes, tsunamis, hurricanes, and geogenic dust; exposure to fibrous minerals such as asbestos and erionite; and the health impacts of global climate change. Billions of people, most in developing countries, are afflicted by these and other environmental health issues that can be avoided, prevented, mitigated or minimized only after detailed and comprehensive research and educational outreach have been conducted and solutions identified, if possible.

This Special Issue of Geosciences marks an important milestone in the global growth and maturation of medical geology. The current Special Issue discusses recent advances in medical 
geology, providing examples from research conducted all over the world. Among the topics to be discussed are:

- Geochemistry of soils and the occurrence of anthrax spores (Griffin et al. [5]);

- Health effect associated with inhalation of airborne arsenic arising from mining operations including coal combustion, hard rock mining and their associated waste products (Martin et al. [6]);

- Risk factors for E. coli O157 and Cryptosporidiosis infection in individuals in the Karst valleys of East Tennessee, USA (Luffman and Tran [7]);

- Assessment of geogenic contaminants in water co-produced with coal seam gas extraction in Queensland, Australia: Implications for human health risk (Stearman et al. [8]);

- Identifying sources and assessing potential risk of exposure to heavy metals and hazardous materials in mining areas: The case study of Panasqueira Mine (Central Portugal) as an example (Candeias et al. [9]);

- Environmental risk assessment based on high-resolution spatial maps of potentially toxic elements sampled on stream sediments of Santiago, Cape Verde (Cabral Pinto et al. [10]);

- The legacy of uranium development on or near Indian Reservations and health implications rekindling public awareness (Moore-Nall A. [11]);

- Exposure to selected geogenic trace elements (I, Li, and $\mathrm{Sr}$ ) from drinking water in Denmark (Voutchkova et al. [12]);

- Potential health risks from uranium in home well water: An investigation by the Apsaalooke (Crow) Tribal Research Group (Eggers et al. [13]);

- Impacts of artisanal and small-scale gold mining (ASGM) on environment and human health of Gorontalo Utara Regency, Gorontalo Province, Indonesia (Arifin et al. [14]).

Finally, this Special Issue follows months of collaboration between the International Medical Geology Association (IMGA) and Geosience journal, and it is result of the commitment of these two organizations of promoting the interest of medical geology worldwide. We believe that with these types of high quality publications, the medical geology community at large will now have an authoritative and influential journal in the geoscience community that would continue to report on significant advances of global impact to the development of medical geology.

Disclaimer: The opinions and/or assertions expressed herein are the private views of the authors, and not be construed as official or as reflecting the views of the U.S. Department of Health and Human Services, the U.S. Food ad Drug Administration or the U.S. Federal Government. Under Title 17 of the USA Code, Section 105, copyright protection is not available for any work of United States Government.

\section{References}

1. Essentials of Medical Geology_Impacts of the Natural Environment on Public Health, 2nd ed.; Selinus, O., Alloway, B., Centeno, J.A., Finkelman, R.B., Fuge, R., Lindh, U., Smedley, P., Eds.; Elsevier: New York, NY, USA, 2013; p. 805.

2. Medical Geology-A Regional Synthesis; Selinus, O., Finkelman, R.B., Centeno, J.A., Eds.; Springer: Berlin, Germany, 2010.

3. Selinus, O.; Finkelman, R.B.; Centeno, J.A. Principles of Medical Geology. In Encyclopedia of Environmental Health; Nriagu, J.O., Ed.; Elsevier: New York, NY, USA, 2011; Volume 2, pp. 669-676.

4. A FIELD ALERT-Health Effects of PAHs in Lignite and Groundwater Supplies. Available online: http:/ / web.i2massociates.com/categories/a-field-alert-health-effects-of-pahs-in-lignite-and-groundwatersupplies.asp (accessed on 19 January 2016).

5. Griffin, D.W.; Silvestri, E.E.; Bowling, C.Y.; Boe, T.; Smith, D.B.; Nichols, T.L. Anthrax and the Geochemistry of Soils in the Contiguous United States. Geosciences 2014, 4, 114-127. [CrossRef]

6. Martin, R.; Dowling, K.; Pearce, D.; Sillitoe, J.; Florentine, S. Health Effects Associated with Inhalation of Airborne Arsenic Arising from Mining Operations. Geosciences 2014, 4, 128-175. [CrossRef] 
7. Luffman, I.; Tran, L. Risk Factors for E. coli O157 and Cryptosporidiosis Infection in Individuals in the Karst Valleys of East Tennessee, USA. Geosciences 2014, 4, 202-218. [CrossRef]

8. Stearman, W.; Taulis, M.; Smith, J.; Corkeron, M. Assessment of Geogenic Contaminants in Water Co-Produced with Coal Seam Gas Extraction in Queensland, Australia: Implications for Human Health Risk. Geosciences 2014, 4, 219-239. [CrossRef]

9. Candeias, C.; da Silva, E.F.; Ávila, P.F.; Teixeira, J.P. Identifying Sources and Assessing Potential Risk of Exposure to Heavy Metals and Hazardous Materials in Mining Areas: The Case Study of Panasqueira Mine (Central Portugal) as an Example. Geosciences 2014, 4, 240-268. [CrossRef]

10. Pinto, M.M.S.C.; Silva, E.A.F.; Silva, M.M.V.G.; Melo-Gonçalves, P.; Candeias, C. Environmental Risk Assessment Based on High-Resolution Spatial Maps of Potentially Toxic Elements Sampled on Stream Sediments of Santiago, Cape Verde. Geosciences 2014, 4, 297-315. [CrossRef]

11. Moore-Nall, A. The Legacy of Uranium Development on or Near Indian Reservations and Health Implications Rekindling Public Awareness. Geosciences 2015, 5, 15-29. [CrossRef]

12. Voutchkova, D.D.; Schullehner, J.; Knudsen, N.N.; Jørgensen, L.F.; Ersbøll, A.K.; Kristiansen, S.M.; Hansen, B. Exposure to Selected Geogenic Trace Elements (I, Li, and Sr) from Drinking Water in Denmark. Geosciences 2015, 5, 45-66. [CrossRef]

13. Eggers, M.J.; Moore-Nall, A.L.; Doyle, J.T.; Lefthand, M.J.; Young, S.L.; Bends, A.L.; Committee, C.E.H.S.; Camper, A.K. Potential Health Risks from Uranium in Home Well Water: An Investigation by the Apsaalooke (Crow) Tribal Research Group. Geosciences 2015, 5, 67-94. [CrossRef]

14. Arifin, Y.I.; Sakakibara, M.; Sera, K. Impacts of Artisanal and Small-Scale Gold Mining (ASGM) on Environment and Human Health of Gorontalo Utara Regency, Gorontalo Province, Indonesia. Geosciences 2015, 5, 160-176. [CrossRef]

(C) 2016 by the authors; licensee MDPI, Basel, Switzerland. This article is an open access article distributed under the terms and conditions of the Creative Commons by Attribution (CC-BY) license (http://creativecommons.org/licenses/by/4.0/). 